\title{
Effects of zinc additions on the microstructure and melting temperatures of $\mathrm{Al}-\mathrm{Si}-\mathrm{Cu}$ filler metals
}

\author{
L.C. Tsao, M.J. Chiang, W.H. Lin, M.D. Cheng, T.H. Chuang* \\ Institute of Materials Science and Engineering, National Taiwan University, 1 Roosevelt Road, \\ Sec. 4, Taipei 106, Taiwan, ROC
}

Received 2 July 2002; accepted 4 July 2002

\begin{abstract}
For the development of a low-melting-point filler metal for brazing aluminum alloys, a series of $\mathrm{Al}-\mathrm{Si}-\mathrm{Cu}-$ $\mathrm{Zn}$ alloys has been studied. Through differential thermal analysis (DTA) analysis, the melting temperatures of such $\mathrm{Al}-\mathrm{Si}-\mathrm{Cu}-\mathrm{Zn}$ filler metals were determined. The results show that the addition of $10-30 \mathrm{wt} . \%$ copper into the traditional Al-12 wt.\% Si filler metal causes its solidus temperature to decrease by about $60{ }^{\circ} \mathrm{C}$. An addition of $10-30$ wt. $\%$ zinc into such $\mathrm{Al}-\mathrm{Si}-\mathrm{Cu}$ ternary alloys will cause their solidus temperatures to drop further to a value lower than $500{ }^{\circ} \mathrm{C}$. Metallographic observations indicate that the addition of zinc into the $\mathrm{Al}-\mathrm{Si}-\mathrm{Cu}$ alloys inhibits the formation of the $\mathrm{Al}-\mathrm{Si}, \mathrm{Al}-\mathrm{Cu}$ and $\mathrm{Al}-\mathrm{Si}-\mathrm{Cu}$ eutectic phases. The remaining phases are a $\mathrm{CuAl}_{2}$ intermetallic compound, an $\alpha-\mathrm{Al}$ solid solution and silicon particles.
\end{abstract}

(C) 2002 Elsevier Science Inc. All rights reserved.

Keywords: $\mathrm{Al}-12 \mathrm{Si}$ alloy; $\mathrm{Al}-\mathrm{Si}-\mathrm{Cu}$ filler; DTA analysis

\section{Introduction}

Among a variety of bonding technologies, brazing has been widely adopted as a reliable method for joining aluminum components [1], wherein the $\mathrm{Al}-$ 12 wt.\% Si alloy is recognized as the most popular filler metal [2,3]. Although a sound joint can be achieved for certain aluminum alloys using this traditional filler metal, its brazing temperature is high in relation to the melting points of these aluminum alloys. As a result, aluminum workpieces during brazing may be partially molten due to the uneven distribution of the temperature within the industrial

* Corresponding author. Tel.: +886-2236-3031; fax: +886-2236-34562.

E-mail address: tunghan@ccms.ntu.edu.tw (T.H. Chuang). furnace. The higher brazing temperature can also cause the degradation of the mechanical properties of aluminum alloys. Even in the more extreme cases of many important engineering aluminum alloys such as 2024, 5083 and $7075 \mathrm{Al}$ alloys, brazing with the traditional $\mathrm{Al}-12 \mathrm{Si}$ filler metal is impractical due to the fact that the solidus temperatures of these aluminum alloys are lower than the eutectic point of the Al-12Si alloy.

In order to solve this problem, many efforts have been made to develop low-melting-point filler metals with a satisfactory bonding strength for brazing most of the aluminum engineering alloys. Kayamoto et al. [4] developed a series of $\mathrm{Al}-\mathrm{Ge}-\mathrm{Si}-\mathrm{Mg}$ filler metals with quite low melting points and sufficient joint strengths for brazing the 6061 aluminum alloy. However, germanium is approximately 400 times the price of aluminum, making such filler metals excessively 
expensive for most applications. Humpston et al. [5] and Jacobson et al. [6] further reported an $\mathrm{Al}-5 \mathrm{Si}-$ $20 \mathrm{Cu}-2 \mathrm{Ni}$ filler metal with a melting temperature range between 518 and $538{ }^{\circ} \mathrm{C}$. When this filler metal was applied to brazing a 3003 aluminum alloy, a shear strength over $75 \mathrm{MPa}$ was obtained. Earlier, Suzuki et al. [7] had also studied a series of ternary eutectic $\mathrm{Al}-\mathrm{Si}-\mathrm{Zn}$ filler metals. They found that by increasing the zinc addition to the $\mathrm{Al}-12 \mathrm{Si}$ filler metal from 0 to $50 \mathrm{wt} . \%$, the eutectic points of such ternary $\mathrm{Al}-\mathrm{Si}-\mathrm{Zn}$ alloys decreased linearly from 577 to $525{ }^{\circ} \mathrm{C}$. In a previous study by the present authors [8], an $\mathrm{Al}-7 \mathrm{Si}-20 \mathrm{Cu}-2 \mathrm{Sn}-1 \mathrm{Mg}$ filler metal with a melting temperature range of $501-522{ }^{\circ} \mathrm{C}$ was developed. When this filler metal was used to braze a 6061-T6 aluminum alloy, an optimized bonding strength of $196 \mathrm{MPa}$ was achieved. In the present study, a series of low-cost $\mathrm{Al}-\mathrm{Si}-\mathrm{Cu}-\mathrm{Zn}$ filler metals with solidus temperatures lower than $500{ }^{\circ} \mathrm{C}$ has been further developed. Their microstructures in correspondence with the thermal properties have been studied.

\section{Experimental}

A series of $\mathrm{Al}-\mathrm{Si}-\mathrm{Cu}-\mathrm{Zn}$ filler metals with various compositions, as shown in Table 1, was prepared for the study. For this purpose, an $\mathrm{Al}-12$ wt.\% Si alloy was melted first at $700{ }^{\circ} \mathrm{C}$ in an air furnace, and then the temperature was raised to 1000

Table 1

Chemical compositions and thermal properties of $\mathrm{Al}-\mathrm{Si}-$ $\mathrm{Cu}-\mathrm{Zn}$ filler metals in this study

\begin{tabular}{|c|c|c|c|c|c|c|c|}
\hline \multirow[t]{2}{*}{ Samples } & \multicolumn{4}{|c|}{$\begin{array}{l}\text { Chemical } \\
\text { compositions (wt.\%) }\end{array}$} & \multirow[t]{2}{*}{$\begin{array}{l}T_{\mathrm{S}}{ }^{\mathrm{a}} \\
\left({ }^{\circ} \mathrm{C}\right)\end{array}$} & \multirow[t]{2}{*}{$\begin{array}{l}T_{\mathrm{L}}{ }^{\mathrm{a}} \\
\left({ }^{\circ} \mathrm{C}\right)\end{array}$} & \multirow[t]{2}{*}{$\begin{array}{l}\Delta T^{\mathrm{a}} \\
\left({ }^{\circ} \mathrm{C}\right)\end{array}$} \\
\hline & $\mathrm{Si}$ & $\mathrm{Cu}$ & $\mathrm{Zn}$ & $\mathrm{Al}$ & & & \\
\hline 1 & 12.0 & 0 & 0 & Bal. & 579 & 593 & 14 \\
\hline 2 & 10.8 & 10 & 0 & Bal. & 518 & 565 & 47 \\
\hline 3 & 9.6 & 10 & 10 & Bal. & 495 & 546 & 51 \\
\hline 4 & 8.4 & 10 & 20 & Bal. & 468 & 535 & 67 \\
\hline 5 & 7.2 & 10 & 30 & Bal. & 446 & 519 & 73 \\
\hline 6 & 10.2 & 15 & 0 & Bal. & 523 & 548 & 25 \\
\hline 7 & 7.0 & 15 & 15 & Bal. & 473 & 526 & 53 \\
\hline 8 & 9.6 & 20 & 0 & Bal. & 524 & 543 & 19 \\
\hline 9 & 8.4 & 20 & 10 & Bal. & 486 & 524 & 38 \\
\hline 10 & 7.2 & 20 & 20 & Bal. & 456 & 496 & 40 \\
\hline 11 & 6.0 & 20 & 30 & Bal. & 429 & 482 & 53 \\
\hline 12 & 8.4 & 30 & 0 & Bal. & 523 & 534 & 11 \\
\hline 13 & 7.2 & 30 & 10 & Bal. & 477 & 532 & 55 \\
\hline 14 & 6.0 & 30 & 20 & Bal. & 434 & 520 & 86 \\
\hline
\end{tabular}

${ }^{a} T_{\mathrm{S}}$ indicates the solidus temperatures of the filler metals. $T_{\mathrm{L}}$ indicates the liquidus temperatures of the filler metals. $\Delta T=T_{\mathrm{L}}-T_{\mathrm{S}}$.
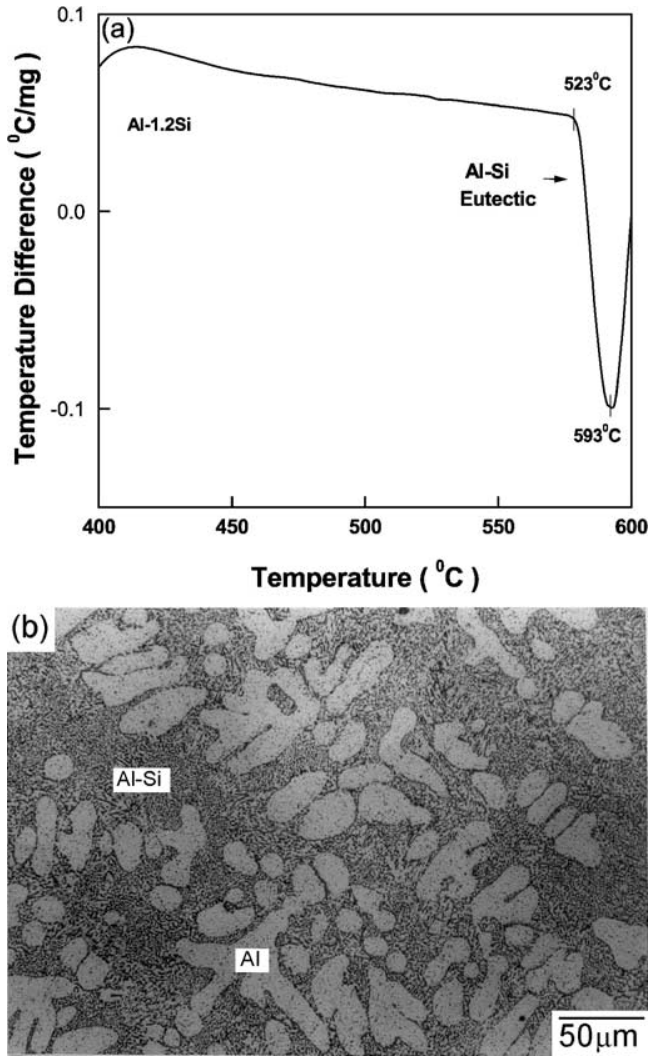

Fig. 1. DTA curve and microstructure of the traditional Al12Si filler metal.

${ }^{\circ} \mathrm{C}$ when various amounts of copper (99.9 wt.\%, 2 $\mathrm{mm}$ diameter slug) were added into the molten $\mathrm{Al}-$ $12 \mathrm{Si}$ alloy. After the mixture was stirred for $30 \mathrm{~min}$ for homogenization, various amounts of zinc were added into the $\mathrm{Al}-\mathrm{Si}-\mathrm{Cu}$ alloys. They were then cast in a stainless steel mold. The solidus and liquidus temperatures of these $\mathrm{Al}-\mathrm{Si}-\mathrm{Cu}-\mathrm{Zn}$ filler metals were measured through differential thermal analysis (DTA). The specimens were heated from room temperature to $600{ }^{\circ} \mathrm{C}$ at a heating rate of $10{ }^{\circ} \mathrm{C} / \mathrm{min}$ under an argon atmosphere. The microstructure was observed by means of optical microscopy after metallographic preparation and etching in 10 vol. $\% \mathrm{H}_{3} \mathrm{PO}_{4}$ at $50{ }^{\circ} \mathrm{C}$ for $60 \mathrm{~s}$.

\section{Results and discussion}

The DTA curve and the corresponding microstructure of a traditional $\mathrm{Al}-12 \mathrm{Si}$ filler metal are shown in Fig. 1a and $1 \mathrm{~b}$ respectively. During the heating process of the DTA analysis, the $\mathrm{Al}-12 \mathrm{Si}$ filler metal shows a nonequilibrium microstructure with a lamellar $\mathrm{Al}-\mathrm{Si}$ eutectic phase and an $\alpha-\mathrm{Al}$ 


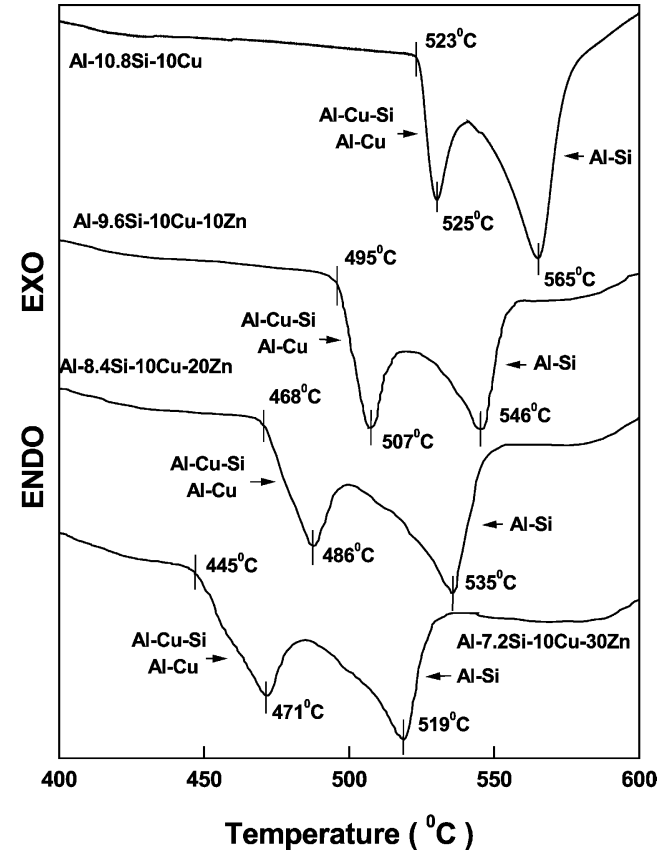

Fig. 2. Effects of $\mathrm{Zn}$ addition on the decrease of solidus and liquidus temperatures for the $\mathrm{Al}-\mathrm{Si}-10 \mathrm{Cu}$ filler metal.

dendrite solid solution. Figs. $2-4$ show the DTA curves of various $\mathrm{Al}-\mathrm{Si}-\mathrm{Cu}-\mathrm{Zn}$ filler metals. The solidi $\left(T_{\mathrm{S}}\right)$ and liquidi $\left(T_{\mathrm{L}}\right)$ of these filler metals obtained from the DTA analyses are summarized in Table 1. It can be seen that the solidus and liquidus temperatures of the traditional $\mathrm{Al}-12 \mathrm{Si}$ filler metal decrease drastically from 579 to $518{ }^{\circ} \mathrm{C}$ and from 593 to $565{ }^{\circ} \mathrm{C}$, respectively, when $10 \%$ copper is added into the alloy. Further addition of zinc into

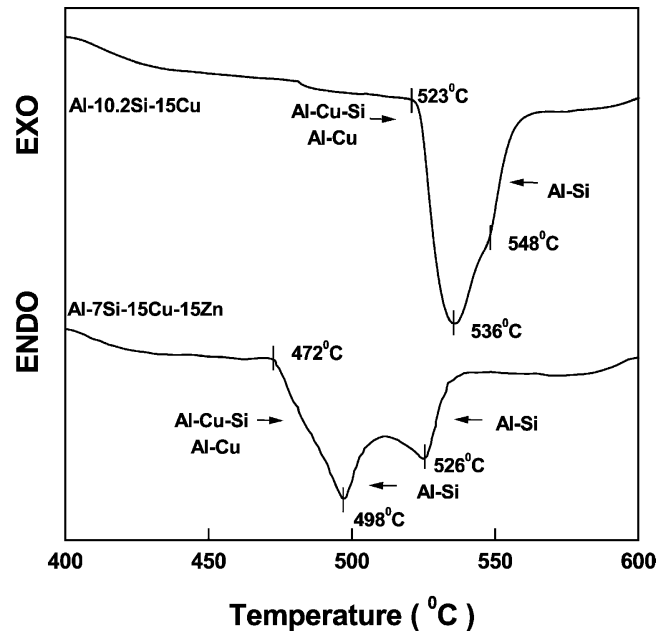

Fig. 3. Effects of $\mathrm{Zn}$ addition on the decrease of solidus and liquidus temperatures for the $\mathrm{Al}-\mathrm{Si}-15 \mathrm{Cu}$ filler metal.

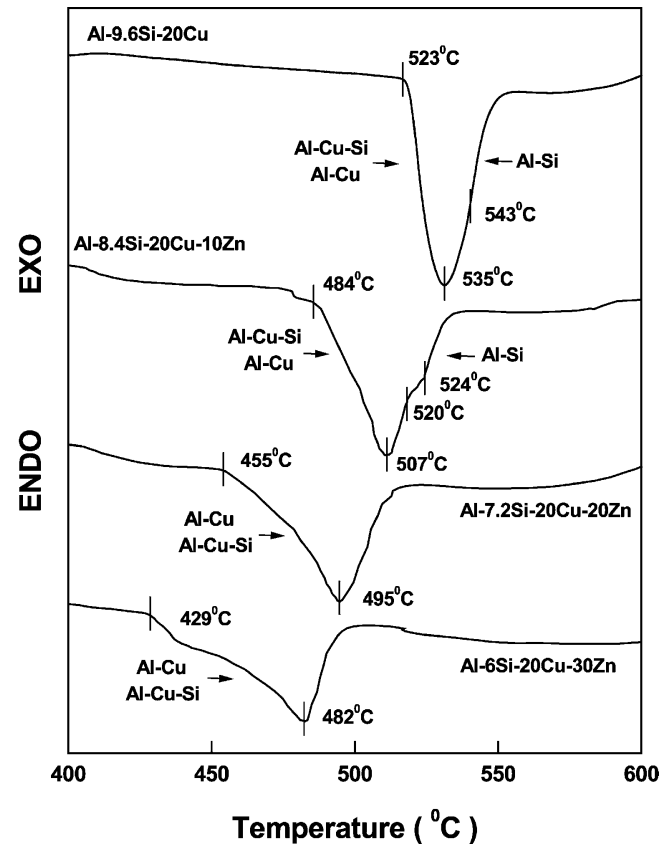

Fig. 4. Effects of $\mathrm{Zn}$ addition on the decrease of solidus and liquidus temperatures for the $\mathrm{Al}-\mathrm{Si}-20 \mathrm{Cu}$ filler metal.

such an $\mathrm{Al}-\mathrm{Si}-10 \mathrm{Cu}$ filler metal causes its solidus and liquidus to plunge further as shown in Fig. 2. From Table 1, it can be estimated that the addition of about $10 \%$ zinc into the $\mathrm{Al}-\mathrm{Si}-10 \mathrm{Cu}$ filler metal results in a decrease of solidus and liquidus temperatures of about 25 and $15{ }^{\circ} \mathrm{C}$, respectively. The declining of solidi and liquidi for the $\mathrm{Al}-\mathrm{Si}-\mathrm{Cu}$ filler metals due to the addition of zinc can be attributed to the low melting point of the zinc element $\left(420{ }^{\circ} \mathrm{C}\right)$, which dissolved with a high solubility in the $\mathrm{Al}-\mathrm{Si}-\mathrm{Cu}$ alloys.

When the copper content of the $\mathrm{Al}-\mathrm{Si}-\mathrm{Cu}$ filler metals is increased from $10 \%$ to $20 \%$, Figs. 3 and 4 show that the solidus temperatures have remained almost constant in the range between 518 and $524{ }^{\circ} \mathrm{C}$. However, the liquidus temperatures still drop sharply to $543{ }^{\circ} \mathrm{C}$ when copper is added up to $20 \%$. Here, the declining phenomenon of solidus and liquidus due to the addition of zinc to the $\mathrm{Al}-\mathrm{Si}-20 \mathrm{Cu}$ filler metal is much more conspicuous than the case of the $\mathrm{Al}-\mathrm{Si}-$ $10 \mathrm{Cu}$ filler metal. In this situation, the addition of about $10 \%$ zinc into the $\mathrm{Al}-\mathrm{Si}-20 \mathrm{Cu}$ filler metal has caused the declination of solidus and liquidus by about 35 and $20{ }^{\circ} \mathrm{C}$, respectively.

As the copper content of the $\mathrm{Al}-\mathrm{Si}-\mathrm{Cu}$ filler metal is further increased from $20 \%$ to $30 \%$, Fig. 5 shows that the solidus temperature has remained constant and the liquidus temperature decreased slightly. An increase in the zinc content of the Al- 


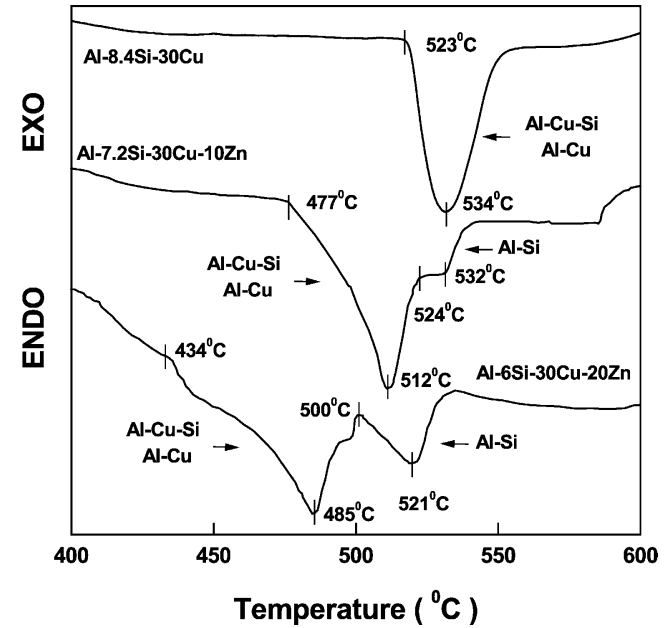

Fig. 5. Effects of $\mathrm{Zn}$ addition on the decrease of solidus and liquidus temperatures for the $\mathrm{Al}-\mathrm{Si}-30 \mathrm{Cu}$ filler metal.

$\mathrm{Si}-30 \mathrm{Cu}$ filler metal results in an obvious declination of the solidus temperature, and, a slight decrease of the liquidus temperature. In this case, the temperature difference between the liquidus and solidus $(\Delta T)$ is wider, which is unfavorable for the brazing process.

The microstructure of the $\mathrm{Al}-10.8 \mathrm{Si}-10 \mathrm{Cu}$ filler metal (Fig. 6a) consists of an $\mathrm{Al}-\mathrm{Cu}-\mathrm{Si}$ ternary
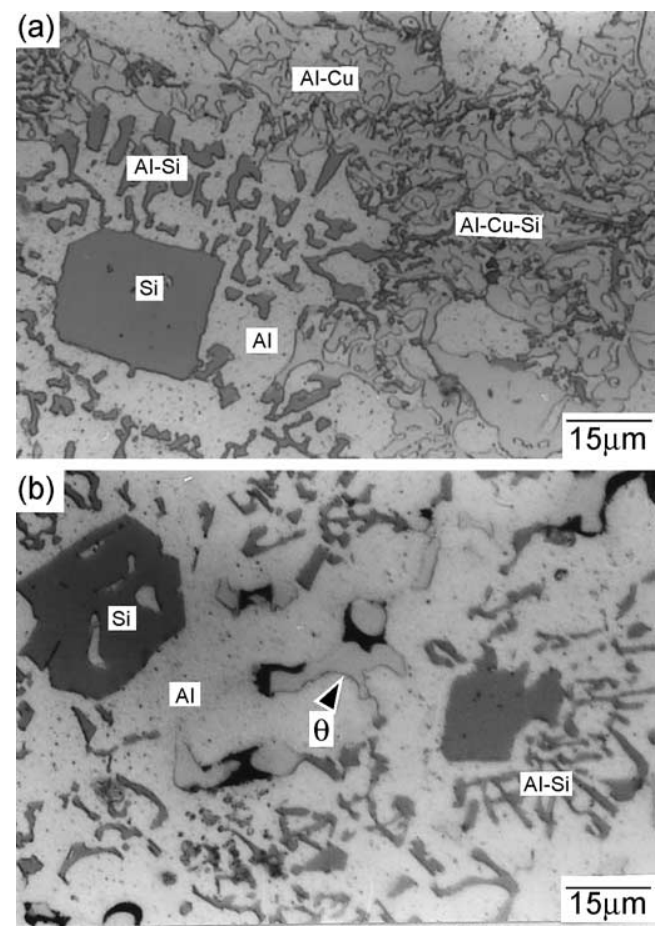

Fig. 6. Microstructures of (a) $\mathrm{Al}-10.8 \mathrm{Si}-10 \mathrm{Cu}$ and (b) $\mathrm{Al}-$ $8.4 \mathrm{Si}-10 \mathrm{Cu}-20 \mathrm{Zn}$ filler metals. eutectic phase, a dendrite $\alpha-\mathrm{Al}$ solid solution, the $\mathrm{CuAl}_{2}(\theta)$ intermetallic compound and some silicon particles with an $\mathrm{Al}-\mathrm{Si}$ eutectic phase surrounding them. Since zinc is highly soluble in aluminum, the addition of zinc to this $\mathrm{Al}-\mathrm{Si}-10 \mathrm{Cu}$ filler metal has not changed of its microstructure much (Fig. 6b). However, it is still noticeable that the amounts of the $\mathrm{CuAl}_{2}(\theta)$ intermetallic compound and the $\mathrm{Al}-\mathrm{Cu}-\mathrm{Si}$ ternary eutectic phase have decreased in the $\mathrm{Al}-\mathrm{Si}-$ $10 \mathrm{Cu}-\mathrm{Zn}$ alloys. The microstructures of the $\mathrm{Al}-\mathrm{Si}-$ $15 \mathrm{Cu}$ and $\mathrm{Al}-\mathrm{Si}-15 \mathrm{Cu}-\mathrm{Zn}$ filler metals as shown in Fig. $7 \mathrm{a}$ and $\mathrm{b}$, respectively, are similar to those found in the $\mathrm{Al}-\mathrm{Si}-10 \mathrm{Cu}$ and $\mathrm{Al}-\mathrm{Si}-10 \mathrm{Cu}-10 \mathrm{Zn}$ alloys. Fig. 8a shows that the $\mathrm{Al}-\mathrm{Si}$ eutectic phase and the dendrite $\alpha$-Al solid solution decrease considerably along with the increasing of the copper content in the $\mathrm{Al}-\mathrm{Si}-\mathrm{Cu}$ filler metal up to $20 \%$. When $10 \%$ zinc is added into the $\mathrm{Al}-\mathrm{Si}-20 \mathrm{Cu}$ filler metal, the $\mathrm{Al}-\mathrm{Si}$ eutectic phase disappears. Fig. $8 \mathrm{~b}$ shows that the $\mathrm{Al}-$ $\mathrm{Cu}$ eutectic structure, the $\mathrm{Al}-\mathrm{Cu}-\mathrm{Si}$ ternary eutectic structure and the $\mathrm{CuAl}_{2}$ intermetallic compound have stayed in the $\mathrm{Al}-\mathrm{Si}-20 \mathrm{Cu}-10 \mathrm{Zn}$ alloy. As the zinc content is increased up to $20 \%$, all of the eutectic phases $(\mathrm{Al}-\mathrm{Si}, \mathrm{Al}-\mathrm{Cu}$ and $\mathrm{Al}-\mathrm{Cu}-\mathrm{Si})$ are replaced by a mixture of the $\mathrm{CuAl}_{2}$ intermetallic compound, an $\alpha-\mathrm{Al}$ solid solution and silicon particles as shown in Fig. 8c. Fig. 8 also indicates that the size of silicon particles has expanded with the increasing of zinc
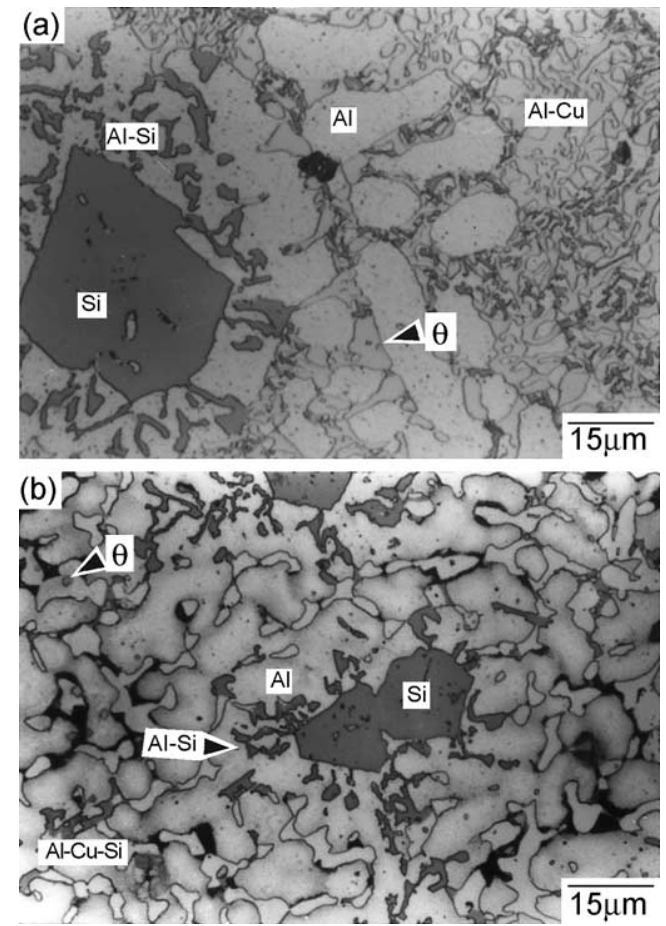

Fig. 7. Microstructures of (a) $\mathrm{Al}-10.8 \mathrm{Si}-15 \mathrm{Cu}$ and (b) $\mathrm{Al}-$ $8.4 \mathrm{Si}-15 \mathrm{Cu}-25 \mathrm{Zn}$ filler metals. 
content in the $\mathrm{Al}-\mathrm{Si}-20 \mathrm{Cu}-\mathrm{Zn}$ alloy. The observations of microstructures in these $\mathrm{Al}-\mathrm{Si}-\mathrm{Cu}-\mathrm{Zn}$ filler metals are consistent with the results of the DTA analysis. On the DTA curves of $\mathrm{Al}-\mathrm{Si}-10 \mathrm{Cu}-\mathrm{Zn}$ (Fig. 2) and $\mathrm{Al}-\mathrm{Si}-15 \mathrm{Cu}-\mathrm{Zn}$ (Fig. 3), two endothermic peaks are observed, as they approach each other for the $\mathrm{Al}-\mathrm{Si}-20 \mathrm{Cu}-\mathrm{Zn}$ alloys (Fig. 4). As for the microstructure of the $\mathrm{Al}-8.4 \mathrm{Si}-30 \mathrm{Cu}$ filler metal shown in Fig. 9a, the $\mathrm{Al}-\mathrm{Si}$ eutectic phases disappears and is replaced by the $\mathrm{Al}-\mathrm{Cu}$ eutectic phase, the $\mathrm{Al}-\mathrm{Cu}-\mathrm{Si}$ ternary eutectic phase and the $\mathrm{CuAl}_{2}$ intermetallic compound as in the case of the $\mathrm{Al}-\mathrm{Si}-$ $20 \mathrm{Cu}-10 \mathrm{Zn}$ filler metal (Fig. 8b). However, the addition of $20 \%$ zinc to such an $\mathrm{Al}-\mathrm{Si}-30 \mathrm{Cu}$ alloy
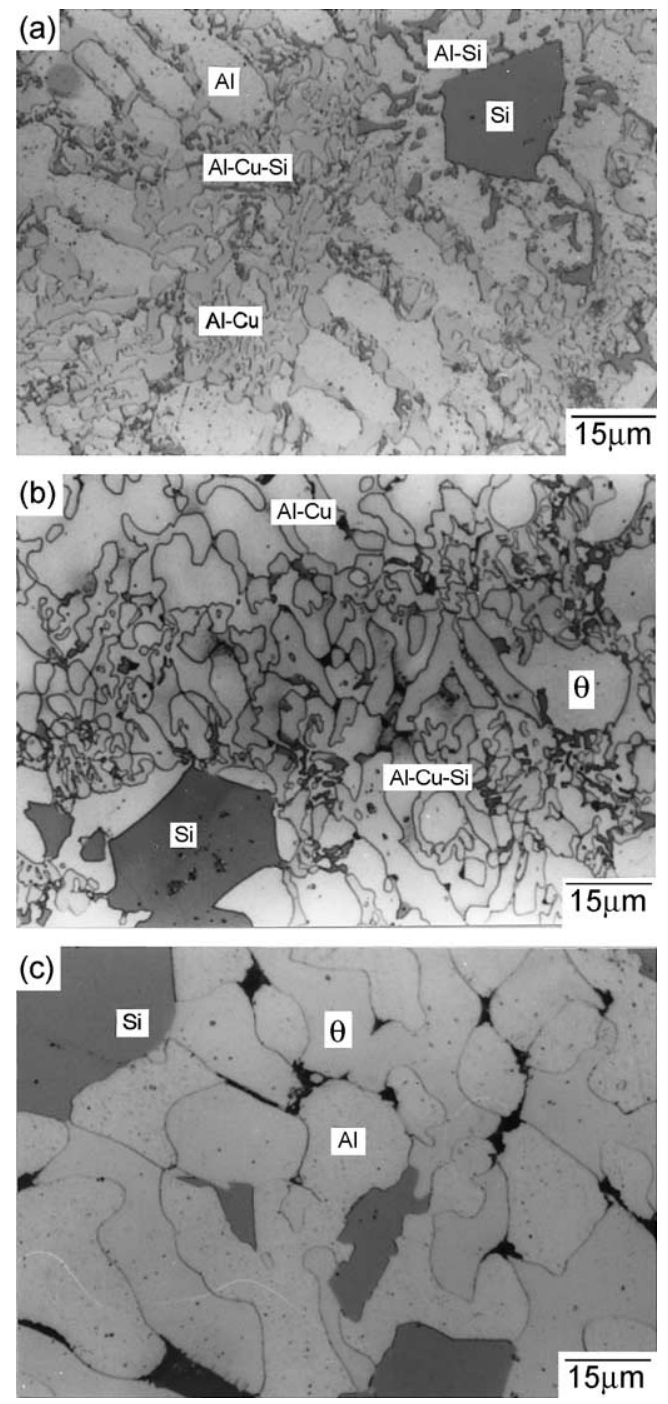

Fig. 8. Microstructures of (a) $\mathrm{Al}-9.6 \mathrm{Si}-15 \mathrm{Cu}$, (b) $\mathrm{Al}-7 \mathrm{Si}-$ $20 \mathrm{Cu}-10 \mathrm{Zn}$, and (c) $\mathrm{Al}-7.2 \mathrm{Si}-20 \mathrm{Cu}-20 \mathrm{Zn}$ filler metals.
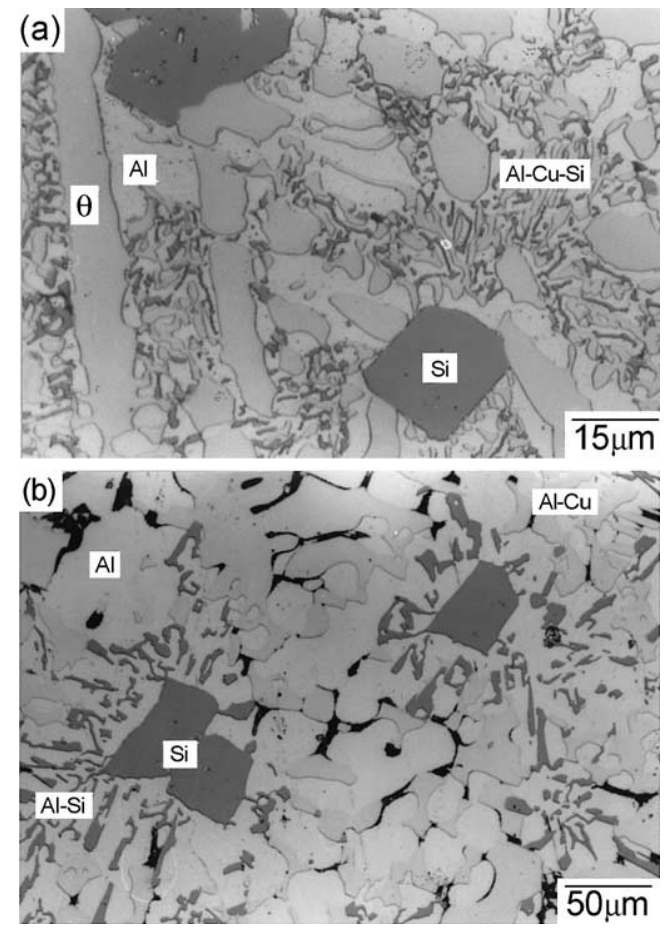

Fig. 9. Microstructures of (a) $\mathrm{Al}-8.4 \mathrm{Si}-30 \mathrm{Cu}$ and (b) $\mathrm{Al}-$ $6 \mathrm{Si}-30 \mathrm{Cu}-20 \mathrm{Zn}$ filler metals.

causes the reappearance of the $\mathrm{Al}-\mathrm{Si}$ eutectic phase (Fig. 9c). The reappearance of the $\mathrm{Al}-\mathrm{Si}$ eutectic phase due to the addition of $20 \%$ zinc to $\mathrm{Al}-\mathrm{Si}-$ $30 \mathrm{Cu}$ is also consistent with the results of the DTA analysis. It can be seen in Fig. 5 that the single endothermic peak on the DTA curve of the Al$8.4 \mathrm{Si}-30 \mathrm{Cu}$ alloy is split into two endothermic peaks on the DTA curve of the $\mathrm{Al}-6 \mathrm{Si} 30 \mathrm{Cu}-20 \mathrm{Zn}$ alloys.

To summarize the results of the thermal analysis and microstructure observations, an $\mathrm{Al}-7.2 \mathrm{Si}-$ $20 \mathrm{Cu}-20 \mathrm{Zn}$ filler metal is suggested, which possesses a melting temperature range between 456 and $496{ }^{\circ} \mathrm{C}$.

\section{Conclusions}

$\mathrm{Al}-\mathrm{Si}-\mathrm{Cu}$ filler metals with a $\mathrm{Cu}$ content between 10 and $30 \mathrm{wt} . \%$ will have solidus temperatures near $520{ }^{\circ} \mathrm{C}$, but these temperatures can be further decreased to a value lower than $500{ }^{\circ} \mathrm{C}$ through the addition of zinc from 10 to $30 \mathrm{wt} . \%$. By adding $20-30$ wt.\% zinc into the $\mathrm{Al}-\mathrm{Si}-20 \mathrm{Cu}$ filler metals, their liquidus temperatures can be lowered to below $500{ }^{\circ} \mathrm{C}$. The microstructures of the $\mathrm{Al}-\mathrm{Si}-\mathrm{Cu}$ filler metals contain eutectic phases (Al-Si, $\mathrm{Al}-\mathrm{Cu}$ and $\mathrm{Al}-\mathrm{Si}-\mathrm{Cu}$ ), a $\mathrm{CuAl}_{2}$ interme- 
tallic compound, an $\alpha-\mathrm{Al}$ solid solution and silicon particles. With the increase of zinc content in the $\mathrm{Al}-\mathrm{Si}-\mathrm{Cu}$ filler metals, the formation of eutectic phases $(\mathrm{Al}-\mathrm{Si}, \mathrm{Al}-\mathrm{Cu}$ and $\mathrm{Al}-\mathrm{Si}-\mathrm{Cu})$ will be restrained.

\section{References}

[1] Sugiyama Y. Brazing of aluminum alloys. Welding Int 1989;3(10):700-10.

[2] Kawas H, Takemoto T, Asano M, Kawakatsu I, Liu K. Study of a method for evaluating the brazeability of aluminum sheet. Welding J 1989;68(10):396s-403s.

[3] Hattori T, Sakai S, Sakamoto A, Fujiwara C. Brazeability of aluminum in vacuum - nitrogen partial-pressure atmosphere brazing. Welding J 1994;73(10):233s-40s.

[4] Kayamoto T, Kim J-H, Saito S, Onzawa T. Brazing of
$\mathrm{Al}-\mathrm{Mg}$ alloy and $\mathrm{Al}-\mathrm{Mg}-\mathrm{Si}$ alloy with $\mathrm{Al}-\mathrm{Ge}$ based filler metals. Proc Workshop J Welding Soc 1994;12(10):495-501.

[5] Humpston G, Sangha S-P-S, Jacobson D-M. New filler metals and process for fluxless brazing of aluminium engineering alloys. Mater Sci Technol 1995; 11(10): $1161-7$.

[6] Jacobson D-M, Humpston G, Sangha S-P-S. A new low-melting-point aluminum braze. Welding J 1996; 75(8):243s-50s.

[7] Suzuki K, Kagayama M, Takeuchi Y. Eutectic phase equilibrium of $\mathrm{Al}-\mathrm{Si}-\mathrm{Zn}$ system and its applicability for lower temperature brazing. J Jpn Inst Light Met 1993;43(10):533-8.

[8] Yeh M-S, Tsao L-C, Tsai T-C, Wu C-S, Chuang T-H. Development of a low-melting-point filler metal for brazing aluminum alloys. Metal Mater Trans 2000; 31A(10):2239-45. 